\title{
Children with rare diseases: do they really have an increased risk of developing epilepsy?
}

\author{
Chiara Pantaleoni ${ }^{*}$ Enrico Alfei, Stefano D’Arrigo \\ From 71st Congress of the Italian Society of Pediatrics. Joint National Meeting SIP, SIMGePeD, Study Group \\ on Pediatric Ultrasound, SUP Study Group on Hypertension \\ Rome, Italy. 4-6 June 2015
}

Symptoms involving the central nervous system (CNS) are frequently part of the variable clinical picture of genetic-dysmorphic syndromes.

Intellectual disability represent the most common associated finding, but epilepsy is very frequently reported, for example in chromosomal abnormalities [1-3].

Seizure risk has been pointed out to be significantly higher in those with chromosomal abnormalities with respect to general population [4-6], and represent an important element to recognize and define for both diagnostic and therapeutic purposes.

Seizures' semeiology, severity and frequency can be highly variable in different syndromes, depending on the type of genetic defect, but even amongst subjects with the same genotype there can be a great variability in clinical manifestations, even intrafamiliarly.

Therefore, within the association between genetic syndromes and epilepsy, we should consider two possible situations:

1) Syndromes in which epilepsy could represent a "specific marker". In certain conditions the recognition of a peculiar electroclinical phenotype could give a significant contribution to diagnostic definition of the syndrome. The best known example is Angelman syndrome $[7,8]$, in which the electroencephalographic (EEG) pattern could suggest the suspected diagnosis even in infants and toddlers, i.e. before the "classical" clinical and behavioral phenotype becomes evident. But epilepsy can represent a significant clinical marker in other conditions as well, such as Rett syndrome [9], Wolf-Hirschhorn

\footnotetext{
* Correspondence: pantaleoni@istituto-besta.it

UO Neurologia dello Sviluppo, IRCCS Fondazione Istituto Neurologico Carlo Besta, Milano, 20133, Italy
}

syndrome [10], and other recently defined deletion or duplication syndromes.

2) Syndromes in which epilepsy is reported occasionally. In these conditions the diagnostic value of the electroclinical phenotype is limited, but the correct identification and treatment of the symptom still has an important effect on individual and familial health and quality of life.

Finally in genetic syndromes some special considerations should be made regarding the role of interictal EEG abnormalities and discussing clinical indications of antiepileptic treatment.

\section{Published: 30 September 2015}

\section{References}

Schinzel A, Niedrist D: Chromosome imbalances associated with epilepsy. Am J Med Genet 2001, 106(2):119-124.

2. Bahi-Buisson N, Ville D, Eisermann M, Plouin P, Kaminska A, Chiron C: Epilepsy in chromosome aberrations. Arch Pediatr 2005, 12(4):449-458.

3. Battaglia A, Guerrini R: Chromosomal disorders associated with epilepsy. Epileptic Disord 2005, 7(3):181-192.

4. Kumada T, Ito M, Miyajima T, Fujii T, Okuno T, Go T, et al: Multi-institutional study on the correlation between chromosomal abnormalities and epilepsy. Brain Dev 2005, 27(2):127-134.

5. Parmeggiani A, Posar A, Giovannini S, Giovanardi-Rossi P: Epilepsy in chromosomal abnormalities: An Italian sample. J Child Neurol 2005, 20(5):419-423.

6. Alfei E, Raviglione F, Franceschetti S, D'Arrigo S, Milani D, Selicorni A, et al: Seizures and EEG features in 74 patients with genetic-dysmorphic syndromes. Am J Med Genet A 2014, 164(12):3154-61.

7. Boyd SG, Harden A, Patton MA: The EEG in early diagnosis of the Angelman (happy puppet) syndrome. Eur J Pediatr 1988, 147(5):508-513.

8. Laan LA, Renier WO, Arts WF, Buntinx IM, Burgt IJ, Stroink VDH, et al: Evolution of epilepsy and EEG findings in Angelman syndrome. Epilepsia 1997, 38(2):195-199

9. Nissenkorn A, Gak E, Vecsler M, Reznik H, Menascu S, Ben Zeev B: Epilepsy in Rett syndrome-The experience of a National Rett Center. Epilepsia 2010, 51(7):1252-1258. 
10. Battaglia A, Filippi T, South ST, Carey JC: Spectrum of epilepsy and electroencephalogram patterns in Wolf-Hirschhorn syndrome:

Experience with 87 patients. Dev Med Child Neurol 2009, 51(5):373-380.

doi:10.1186/1824-7288-41-S2-A53

Cite this article as: Pantaleoni et al:: Children with rare diseases: do they really have an increased risk of developing epilepsy? Italian Journal of Pediatrics 2015 41(Suppl 2):A53.

Submit your next manuscript to BioMed Central and take full advantage of:

- Convenient online submission

- Thorough peer review

- No space constraints or color figure charges

- Immediate publication on acceptance

- Inclusion in PubMed, CAS, Scopus and Google Scholar

- Research which is freely available for redistribution

Submit your manuscript at www.biomedcentral.com/submit
() Biomed Central 